ARTICLE

\title{
In-situ abiogenic methane synthesis from diamond and graphite under geologically relevant conditions
}

Miriam Peña-Alvarez ${ }^{1}$, Alberto Vitale Brovarone ${ }^{2,3}$, Mary-Ellen Donnelly ${ }^{4}$, Mengnan Wang ${ }^{1}$, Philip Dalladay-Simpson ${ }^{4}$, Ross Howie ${ }^{4} \&$ Eugene Gregoryanz ${ }^{1,4,5}$

Diamond and graphite are fundamental sources of carbon in the upper mantle, and their reactivity with $\mathrm{H}_{2}$-rich fluids present at these depths may represent the key to unravelling deep abiotic hydrocarbon formation. We demonstrate an unexpected high reactivity between carbons' most common allotropes, diamond and graphite, with hydrogen at conditions comparable with those in the Earth's upper mantle along subduction zone thermal gradients. Between 0.5-3 GPa and at temperatures as low as $300^{\circ} \mathrm{C}$, carbon reacts readily with $\mathrm{H}_{2}$ yielding methane $\left(\mathrm{CH}_{4}\right)$, whilst at higher temperatures $\left(500^{\circ} \mathrm{C}\right.$ and above), additional light hydrocarbons such as ethane $\left(\mathrm{C}_{2} \mathrm{H}_{6}\right)$ emerge. These results suggest that the interaction between deep $\mathrm{H}_{2}$-rich fluids and reduced carbon minerals may be an efficient mechanism for producing abiotic hydrocarbons at the upper mantle.

\footnotetext{
${ }^{1}$ Centre for Science at Extreme Conditions and School of Physics and Astronomy, University of Edinburgh, Edinburgh, UK. ${ }^{2}$ Dipartimento di Scienze Biologiche, Geologiche e Ambientali (BiGeA), Alma Mater Studiorum Università di Bologna, Piazza di Porta San Donato 1, 40126 Bologna, Italy. ${ }^{3}$ Sorbonne Université, Muséum National d'Histoire Naturelle, UMR CNRS 7590, IRD, Institut de Mináralogie, de Physique des Matáriaux et de Cosmochimie, IMPMC, 75005 Paris, France. ${ }^{4}$ Center for High Pressure Science and Technology Advanced Research (HPSTAR), Shanghai, China. ${ }^{5}$ Key Laboratory of Materials Physics, Institute of Solid State Physics, Chinese Academy of Sciences, Hefei, China. ${ }^{凶}$ email: e.gregoryanz@ed.ac.uk
} 
$\mathrm{T}$ he process of abiotic hydrocarbon formation in the deep Earth is still contested, despite being central in geobiological processes and potential natural energy sources $^{1,2}$. Light hydrocarbons of abiotic origin have been identified in an increasing number of geological fluids in the Earth's lithosphere ${ }^{3-6}$. Methane has also been detected within deep diamonds, suggesting the presence of abiotic hydrocarbons at mantle depths ${ }^{7-9}$. However, their formation mechanisms and distribution, as well as their possibility to degas towards the crust and the atmosphere, remain largely unconstrained. The abiotic formation of stable light hydrocarbons, such as methane $\left(\mathrm{CH}_{4}\right)$, was mainly considered to occur through reduction paths and, generally, in the presence of oxygen carrying species such as carbon monoxide (CO) or carbon dioxide $\left(\mathrm{CO}_{2}\right)$ through the so-called Fischer-Tropsch Type reactions ${ }^{10-14}$.

In the Earth's interior, diamond and graphite are the major carbon reservoirs ${ }^{14}$, whereas hydrogen $\left(\mathrm{H}_{2}\right)$ is among the most volatile fluid elements. Graphite and other forms of carbonaceous materials are dominant at depths between 50 and $140 \mathrm{~km}$ $(2-4 \mathrm{GPa})^{14-16}$, whereas deeper than $140 \mathrm{~km}$ depth $(4 \mathrm{GPa})$ diamond becomes stable ${ }^{17}$. In Fig. 1, we summarize the relationship between pressure, in deep in the Earth's mantle, and the evolution of the distribution of graphite and diamond, together with hydrogen and methane clusters.

Methane may be a fundamental component of upper mantle fluids ${ }^{14}$. It reacts under high pressure, forming long-chain hydrocarbons, and then it is predicted to eventually dissociate into diamond, graphitic carbon and hydrogen ${ }^{18-21}$. Methane at depths could co-exist with molecular hydrogen $\left(\mathrm{H}_{2}\right)$ and small amounts of light hydrocarbons and different carbon allotropes ${ }^{10,13,14}$. However, the origin of methane in the upper mantle remains largely unconstrained ${ }^{2}$.

Reactions between $\mathrm{H}_{2}$-rich fluids and carbon-bearing parent minerals may be effective to produce methane and other hydrocarbons abiotically. At upper mantle conditions, $\mathrm{H}_{2}$ may be present and immiscible in aqueous fluids, and react with condensed carbon minerals ${ }^{22-26}$. Water-rock interactions at subduction zone conditions may also be effective in generating $\mathrm{H}_{2}$-rich fluids ${ }^{6,27-31}$, also in the presence of graphite $25,32,33$. Molecular hydrogen may also be present in minerals at upper mantle conditions ${ }^{34}$. Recent analysis of fluid inclusions in super-deep diamonds indicates that $\mathrm{H}_{2}$ may represent a significant component of upper mantle fluids in the presence of diamond ${ }^{7,8}$. Yet, reactivity between diamond and $\mathrm{H}_{2}$ at upper mantle conditions has not been contemplated as a source of abiogenic hydrocarbons.

Here we investigate abiotic methane production from the precursors of pure $\mathrm{H}_{2}$ and condensed carbon minerals such as diamond and graphite. We conduct in situ experiments using a resistively heated diamond anvil cell (DAC) at pressure and temperature conditions in the range of $0.5-5 \mathrm{GPa}$ and $300-730^{\circ} \mathrm{C}$, and use Raman spectroscopy as the diagnostic tool. Most of the investigated conditions are consistent with Earth's upper mantle and subduction zone $P-T$ (pressure and temperature) gradients ${ }^{35}$. We find that at these mild $P-T$ conditions, diamond and graphite react readily with $\mathrm{H}_{2}$ to form methane and other light hydrocarbons, such as ethane $\left(\mathrm{C}_{2} \mathrm{H}_{6}\right)$. This demonstrates that the reaction between condensed carbon phases and $\mathrm{H}_{2}$ could be an important source of abiotic hydrocarbons, which should be considered in the deep Earth's carbon cycle.

\section{Results}

Diamond and hydrogen. At room temperature and at pressures between 2 and $3 \mathrm{GPa}$, Raman measurements show only the characteristic spectrum of the $\mathrm{H}_{2}$ sample, and that of the diamond anvils (Fig. 2). Heating hydrogen in a DAC at $2 \mathrm{GPa}$ (which corresponds to Earth depths of about $70 \mathrm{~km}^{36}$, see Fig. 1) to temperatures of $500^{\circ} \mathrm{C}$, we observe a new Raman band appearing at $\sim 2900 \mathrm{~cm}^{-1}$ within $\sim 20 \mathrm{~min}$ (see Fig. 2). This new band can be detected uniformly across the sample chamber. Repeating measurements at $3 \mathrm{GPa}$ (below or around $70 \mathrm{~km}$ depth, see Fig. 1) and holding the sample at lower temperatures of $300{ }^{\circ} \mathrm{C}$ for a period of $2 \mathrm{~h}$, the same results are observed; a new band at $2900 \mathrm{~cm}^{-1}$ appears and its intensity grows with time. This new mode coincides with the most intense $\mathrm{C}-\mathrm{H}$ vibrational

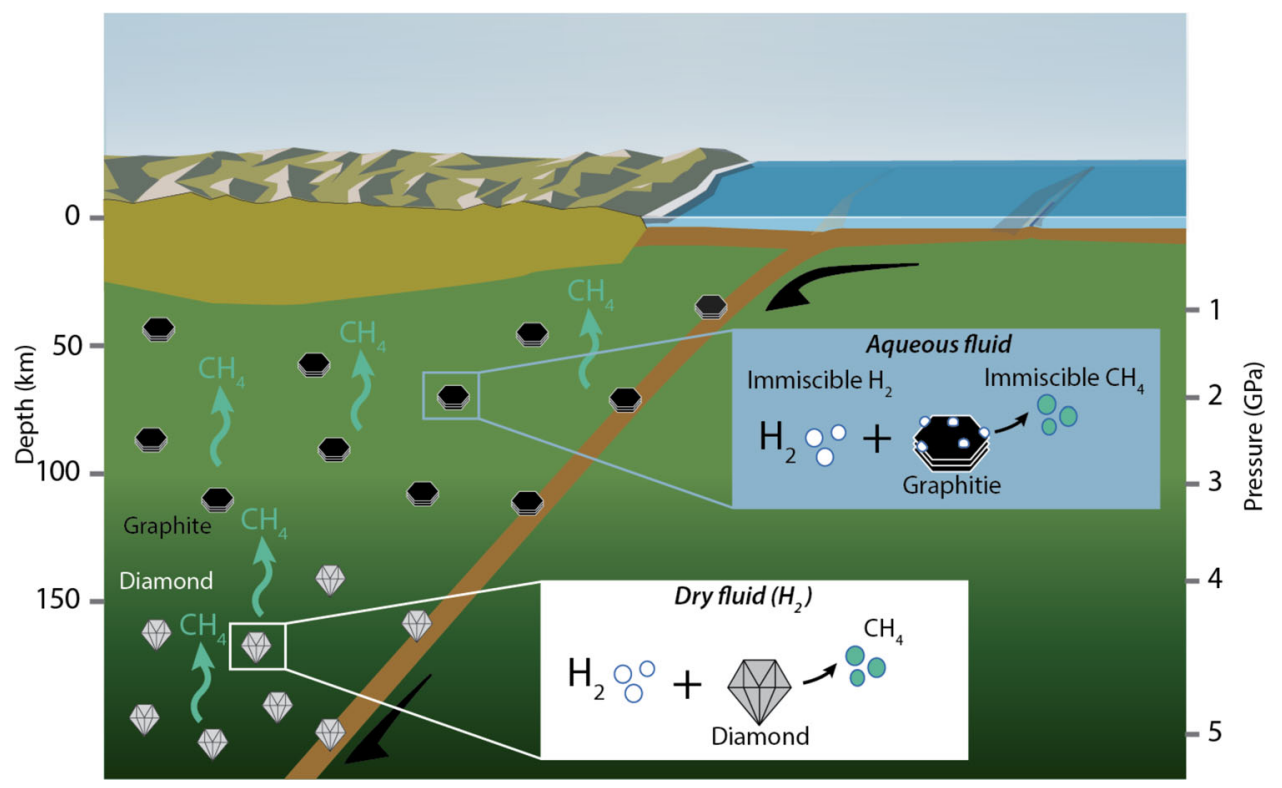

Fig. 1 Sketch modified after Fig. 1 in Li et al. ${ }^{52}$ summarizing the implications of this study on the genesis of abiotic $\mathbf{C H}_{\mathbf{4}}$ in the upper mantle. Below about $140 \mathrm{~km}$ depth ( $4 \mathrm{GPa}$ ), the immiscibility of $\mathrm{H}_{2}$ in aqueous fluids ${ }^{22}$ can promote interactions between $\mathrm{H}_{2}$ gas and graphitic carbon, leading to the formation of $\mathrm{CH}_{4}$ (Fig. 3). This condition is plausible in reducing settings with low oxygen concentrations within the upper mantle ${ }^{17}$ or where reducing conditions are generated in subduction zones ${ }^{25}$. At greater depths in the diamond stability field, the oxygen fugacity is predicted to be lower ${ }^{14}$ and dry $\mathrm{H}_{2}$ fluids are more common 7,8 and interact with diamond to form abiotic $\mathrm{CH}_{4}$ (Fig. 1). 

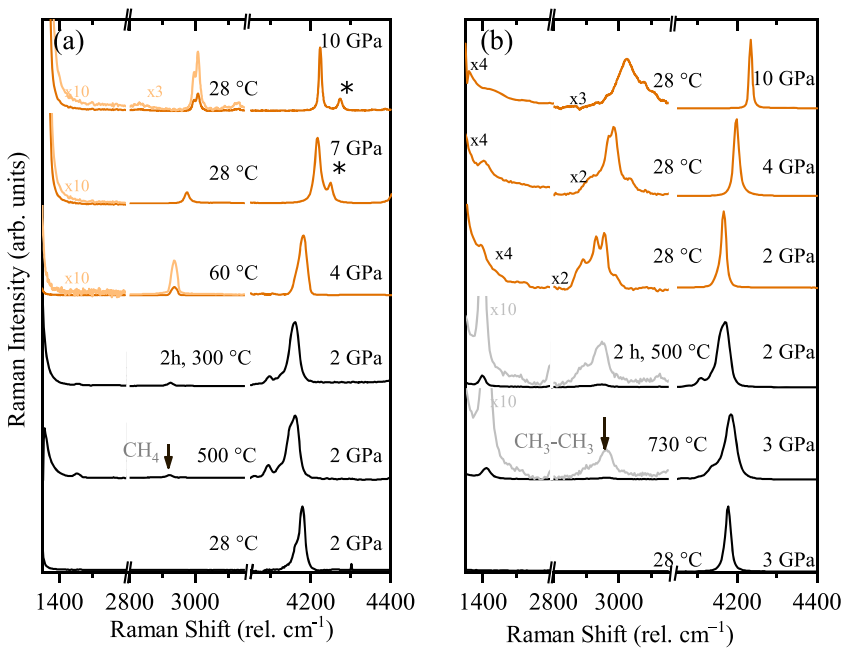

Fig. 2 Raman spectra of resistive heating of hydrogen in a diamond anvil cell at selected pressures and temperatures. a Up to a maximum temperature of $500^{\circ} \mathrm{C}$ and held at $300^{\circ} \mathrm{C}$ for $2 \mathrm{~h}$ and after cooling down. Orange spectra correspond to the cooled down sample. $\mathbf{b}$ Up to a maximum temperature of $730^{\circ} \mathrm{C}$ and held at $500^{\circ} \mathrm{C}$ for $2 \mathrm{~h}$ and after cooling down. Orange spectra correspond to cooled down sample. The $\mathrm{CH}$ stretching modes of $\mathrm{CH}_{4}(\mathbf{a})$ and $\mathrm{C}_{2} \mathrm{H}_{6}(\mathbf{b})$ appear between 2900 and $3000 \mathrm{~cm}^{-1}$. In the cooled down sample of experiment $\mathbf{b}$, the $\mathrm{CH}$ wagging mode is seen at around $1480 \mathrm{~cm}^{-1}$. The band at around $4200 \mathrm{~cm}^{-1}$ corresponds to the vibrational mode of $\mathrm{H}_{2}\left(Q_{1}{ }^{50}\right.$, this is accompanied by the rotational + vibrational band $\left(Q_{1}+S_{0}\right)$ visible in liquid hydrogen. At high temperatures, there is another band at lower frequency, which corresponds to the thermally populated second vibrational state of hydrogen ${ }^{51}$. Asterisks mark the vibrational mode from the $\mathrm{CH}_{4}-\mathrm{H}_{2}$ van der Waals compounds ${ }^{41}$.

stretching mode of methane, indicating abiotic methane production from the only elements present in the experimental chamber: hydrogen and diamond.

High-temperature studies of dense methane have yielded other light hydrocarbons such as ethane $\left(\mathrm{C}_{2} \mathrm{H}_{6}\right)$, propane $\left(\mathrm{C}_{3} \mathrm{H}_{8}\right)$, butane $\left(\mathrm{C}_{4} \mathrm{H}_{10}\right)$ and isobutane $\left(\mathrm{C}_{4} \mathrm{H}_{10}\right)^{19}$. In our experiments, increasing temperature to $730^{\circ} \mathrm{C}$ at $3 \mathrm{GPa}$ leads to the growth of more complex vibrational excitations, centred around $\sim 2950 \mathrm{~cm}^{-1}$ (Fig. 2b). The intensity of these modes increases with time if the sample is held at above $500{ }^{\circ} \mathrm{C}$ for $2 \mathrm{~h}$. By comparing the obtained spectrum with spectra reported for hydrocarbons in the literature ${ }^{37-39}$, we can identify the additional product as ethane $\left(\mathrm{C}_{2} \mathrm{H}_{6}\right)$. Upon temperature quenching, samples were subsequently compressed up to $30 \mathrm{GPa}$ at room temperature. The evolution of the vibrational spectra and their frequencies vs. pressure are in good agreement with those of methane and ethane (Supplementary Fig. 2) $37,40,41$. We also note that at above $5 \mathrm{GPa}$, we observe an additional vibrational mode, which is present neither in pure methane nor in hydrogen (see mode indicated by asterisks in Fig. 2a). This new mode has previously been interpreted as being a feature of a $\mathrm{CH}_{4}-\mathrm{H}_{2}$ van der Waals compounds ${ }^{41}$. Experiments were repeated using deuterium as a precursor instead of hydrogen, in which we observed the formation of $\mathrm{CD}_{4}$ (Supplementary Fig. 1). The presence of $\mathrm{CD}_{4}$ after heating is evidence that the reaction is between the $D_{2}$ sample and diamond, and not from residuals and/or a contaminant from the preparation process.

We performed three control experiments to eliminate the possibility of carbon contaminants in the sample chamber, whereby the gasket and diamonds were insulated from the hydrogen sample with aluminium oxide $\left(\mathrm{Al}_{2} \mathrm{O}_{3}\right)$ (see Fig. 3). $\mathrm{Al}_{2} \mathrm{O}_{3}$ has been shown to provide a protective layer that slows down hydrogen diffusion into diamond at high pressures and
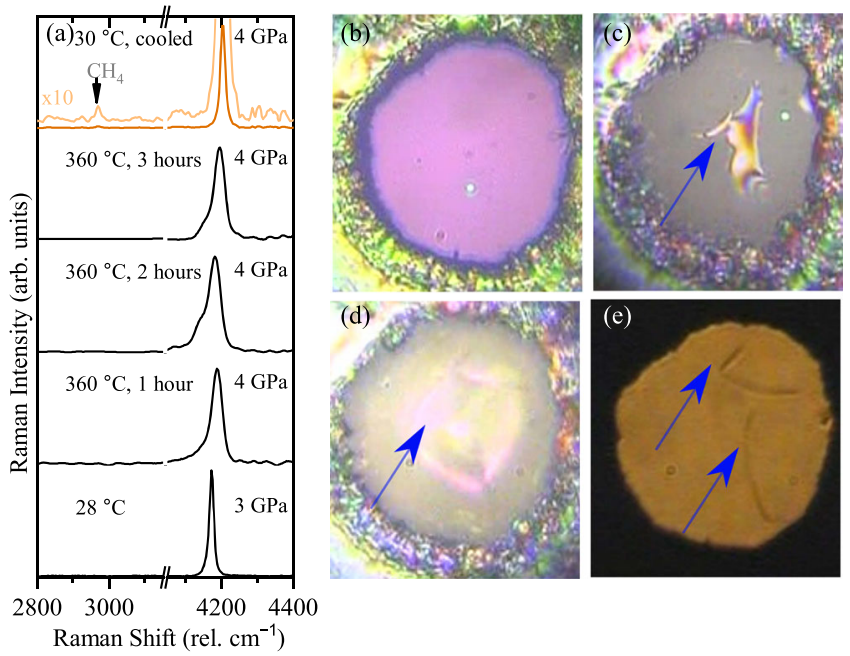

Fig. 3 Hydrogen sample resistively heated during heating and cooling process at $3 \mathrm{GPa}$, using a diamond anvil cell whose culets and gasket

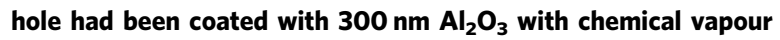

deposition. a Representative Raman spectra during heating and cooling (orange spectrum). b Image taken in transmitted and reflected light, while being heated at $360^{\circ} \mathrm{C}$ for $1 \mathrm{~h}$. c Image of the sample at $360^{\circ} \mathrm{C}$ for $3 \mathrm{~h}$, the image has been taken in reflected light so the region of the chamber where coating is becoming damaged is seen. d Image of the sample after cooling in transmitted light. e Image of the sample after cooling down only in transmitted light. Blue arrows are used to point the regions of the damaged $\mathrm{Al}_{2} \mathrm{O}_{3}$ layer; green spots are due to the laser beam.

temperatures ${ }^{42}$. Therefore, it could preclude the formation of $\mathrm{CH}_{4}$ from the diamond anvil and hydrogen. Inspection of the optical images of the sample chamber after $1 \mathrm{~h}$ at $360^{\circ} \mathrm{C}$ and $4 \mathrm{GPa}$ reveals that the coating was still pristine (Fig. $3 \mathrm{~b}$ ) and no methane was observed spectroscopically. However, after $3 \mathrm{~h}$ at this temperature, part of the coating began breaking up and detaching from the diamond (Fig. 3c), becoming more visible during the cooling of the sample (Fig. $3 \mathrm{~d}-\mathrm{e}$ ). This deterioration of the coating with temperature and time enabled hydrogen to reach the diamonds, forming methane on contact. We also considered that the transition metals from which the gaskets are made, could catalyse the reactions ${ }^{43}$. We conducted several heating runs with different gasket materials such as rhenium $(\mathrm{Re})$ and tungsten $(\mathrm{W})$, and gasket liners, e.g., gold (Au) and $\mathrm{Al}_{2} \mathrm{O}_{3}$ (see Supplementary Table 1 for a list of the materials used). We observed that, regardless of the gasket and gasket insert materials, if the diamonds are not protected by $\mathrm{Al}_{2} \mathrm{O}_{3}, \mathrm{CH}_{4}$ and/or $\mathrm{C}_{2} \mathrm{H}_{6}$ are always produced.

Graphite, glass-like carbon and hydrogen. As graphite may be an important component of subducted sedimentary rocks ${ }^{44-46}$, we repeated our experiments by adding graphite into the sample chamber. These experimental runs yielded identical results producing larger amounts of methane on a shorter timescale than with the diamond precursor. We also explored the reactivity of disordered carbonaceous materials using a glass-like form of carbon (for which thermodynamic data are available ${ }^{46}$ ), which may be common below $500-600{ }^{\circ} \mathrm{C}$ in subduction zones ${ }^{15}$. Figure 4 shows the Raman spectra between 1.0 and $1.5 \mathrm{GPa}$ during heating cycles of (a) $\mathrm{H}_{2}$-graphite and (b) $\mathrm{H}_{2}$-glassy-like carbon. In both cases, there is a rapid growth of the $\mathrm{C}-\mathrm{H}$ stretching mode of methane with time. Similar to the methane production from diamond, $\mathrm{CH}_{4}$ forms compounds with $\mathrm{H}_{2}$ on compression of the quenched sample ${ }^{41}$. 

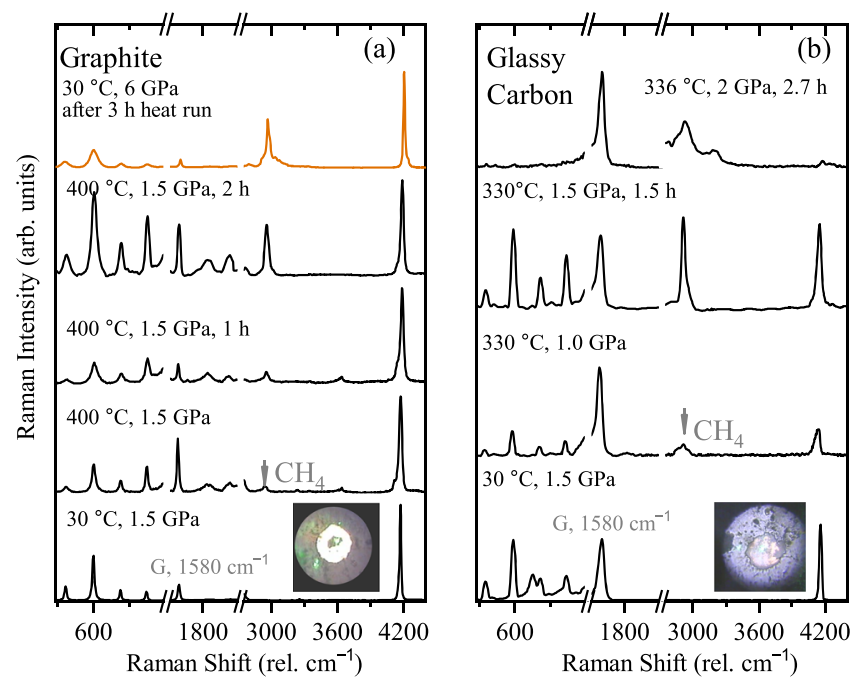

Fig. 4 Resistive heating of hydrogen in a diamond anvil cell. a Graphite loaded together with $\mathrm{H}_{2}$, spectra at selected temperatures and pressure. Spectra have been normalized to the $\mathrm{H}_{2}$ stretching mode, around $4200 \mathrm{~cm}^{-1}$. Orange spectrum correspond to the quenched sample. b Glassy-like carbon loaded together with $\mathrm{H}_{2}$, spectra are normalized to the $\mathrm{G}$ band characteristic of carbonaceous materials at around $1580 \mathrm{~cm}^{-1}$. Inserted images correspond to the sample within the diamond anvil cell chamber during the experiment.

\section{Discussion}

In each of the graphite and glassy carbon experiments, similar amounts of samples were used. Comparing the intensities of methane produced by different carbonaceous samples, one can conclude that glassy-like carbon and graphite are naturally more reactive to $\mathrm{H}_{2}$ than diamond (see Supplementary Fig. 4 to compare the relative intensities of methane peaks generated from the different starting materials). Of course, this statement is tentative and approximate, as the graphite and glassy-like carbon measurements also contain a contribution from the methane formed from the diamond anvils and there are other factors such as background and hydrogen accessibility to the carbonaceous sample that influence the experiment. Nevertheless, this suggests that graphitic carbon materials can act as an efficient reactant for abiotic $\mathrm{CH}_{4}$ formation in upper mantle and crustal environments.

Condensed carbon reservoirs and their mobilization in deep fluids may represent a key to unravelling deep carbon recycling. We have shown that under dry conditions, and in the absence of oxygen or a catalyst, methane is formed from diamond, graphite or glassy carbon and hydrogen, at conditions comparable to the outer layers of the Earth's mantle (depths of $18-160 \mathrm{~km}$, pressures of $0.5-5 \mathrm{GPa}$ and temperatures between $300^{\circ} \mathrm{C}$ and $730{ }^{\circ} \mathrm{C}$ ). Fluids rich in $\mathrm{H}_{2}$ may be common in the upper mantle and generated by fluid-rock or melt-rock reactions ${ }^{6,6,47}$, or dissolved in minerals ${ }^{34}$. Moreover, immiscibility of $\mathrm{H}_{2}$ or $\mathrm{H}_{2}-\mathrm{CH}_{4}$ in aqueous fluids in the graphite or diamond stability field ${ }^{22-25}$ could extend the effectiveness of our results to local fluid-mineral interactions in oxygen-bearing systems. Fig. 1 summarizes the main results of this work, in which we propose that hydrogen and different reduced carbon species found in the Earth's mantle could be an important source of abiogenic hydrocarbons. Our results provide a possible explanation for geological findings of the detection of methane and hydrogen in diamonds extracted from the lower mantle ${ }^{7,8}$. Thus, the different species might contribute to the cycling of deep carbon in the Earth's upper mantle via methane production and act as sources of deep energy for shallower reservoirs $1,6,48$.

\section{Methods}

Ultra-low fluorescent diamond anvils, with culet diameters ranging between 200 and $300 \mu \mathrm{m}$, were used. Re-foil or W-foil gaskets were used to contain the samples. No differences were found when using Re or W, or Au-lined Re gaskets. Researchgrade $(99.9999 \%)$ hydrogen and deuterium samples were gas loaded into DACs at a pressure of $0.2 \mathrm{GPa}$. Prior to gas loading, the diamond surfaces were thoroughly cleaned with several washes, first with acetone and then with of doubly distilled deionized water and the use of organic solvents was avoided. The gasket was first cleaned in water in an ultrasonic bath and then placed on the diamond surface for immediate loading. After loading, samples were mapped with Raman spectroscopy to rule out any possible contamination. High-purity graphite (99.8\%, 43078 Alfa Aesar) and glass-like spherical powder by Alpha Aesar were loaded into the DAC, and research-grade hydrogen (99.9999\%) was subsequently gas loaded at a pressure of $0.2 \mathrm{GPa} . \mathrm{Al}_{2} \mathrm{O}_{3}$ coatings were done via chemical vapour deposition. High-quality Raman spectra were acquired using a custom-built micro-focused Raman system, using a $514 \mathrm{~nm}$ laser as the excitation line. High-temperature experiments were conducted using modified high-temperature Mao-Bell DACs equipped with a primary and a secondary heater, and thermocouples. A type- $\mathrm{K}$ thermocouple was partially clamped between the gasket and the diamond anvil. Good mechanical contact ensures a more accurate temperature measurement, while ensuring optimum proximity to the sample chamber. Heating was done in two stages: (i) the primary, external to the cell assembly heating to $500^{\circ} \mathrm{C}$; and (ii) a secondary internal heater, situated around the diamond anvils, heating to $730{ }^{\circ} \mathrm{C}$. The secondary heater made of a Mo-coil heating element was driven by a DC power supply on a feedback loop with a high sampling rate controller ${ }^{49-51}$.

\section{Data availability}

The data that support the findings of this study are available from the corresponding author upon request.

Received: 24 May 2021; Accepted: 8 October 2021; Published online: 04 November 2021

\section{References}

1. Gold, T. The deep, hot biosphere. Proc. Natl Acad. Sci. USA 89, 6045-6049 (1992).

2. Sephton, M. A. \& Hazen, R. M. On the origins of deep hydrocarbons. Rev. Mineral. Geochem. 75, 449-465 (2013).

3. Charlou, J., Donval, J., Fouquet, Y., Jean-Baptiste, P. \& Holm, N. Geochemistry of high $\mathrm{h}_{2}$ and $\mathrm{ch}_{4}$ vent fluids issuing from ultramafic rocks at the rainbow hydrothermal field. Chem. Geo. 191, 345-359 (2002).

4. Etiope, G. \& Sherwood Lollar, B. Abiotic methane on earth. Rev. Geophys. 51, 276-299 (2013).

5. Young, E. et al. The relative abundances of resolved ${ }^{12} \mathrm{CH}_{2} \mathrm{D}_{2}$ and ${ }^{13} \mathrm{CH}_{3} \mathrm{D}$ and mechanisms controlling isotopic bond ordering in abiotic and biotic methane gases. Geochim. Cosmochim. Acta 203, 235-264 (2017).

6. Vitale-Brovarone, A. et al. Subduction hides high-pressure sources of energy that may feed the deep subsurface biosphere. Nat. Commun. 11, 1-11 (2020).

7. Smith, E. M. et al. Large gem diamonds from metallic liquid in Earth's deep mantle. Science 354, 1403-1405 (2016).

8. Smith, E. M. et al. Blue boron-bearing diamonds from Earth's lower mantle. Nature 560, 84-87 (2018).

9. Smit, K. V., Shirey, S. B., Stern, R. A., Steele, A. \& Wang, W. Diamond growth from $\mathrm{C}-\mathrm{H}-\mathrm{N}-\mathrm{O}$ recycled fluids in the lithosphere: evidence from $\mathrm{CH}_{4}$ microinclusions and $\delta^{13} \mathrm{C}-\delta^{15} \mathrm{~N}-\mathrm{N}$ content in marange mixed-habit diamonds. Lithos 265, 68-81 (2016).

10. Anderson, R. B., Kölbel, H. \& Ralek, M. The Fischer-Tropsch Synthesis Vol. 16 (Academic, 1984).

11. McCollom, T. M. Laboratory simulations of abiotic hydrocarbon formation in Earth's deep subsurface. Rev. Mineral. Geochem. 75, 467-494 (2013).

12. McCollom, T. M. Abiotic methane formation during experimental serpentinization of olivine. Proc. Natl Acad. Sci. USA 113, 13965-13970 (2016).

13. Spanu, L., Donadio, D., Hohl, D., Schwegler, E. \& Galli, G. Stability of hydrocarbons at deep earth pressures and temperatures. Proc. Natl Acad. Sci. USA 108, 6843-6846 (2011)

14. Frost, D. J. \& McCammon, C. A. The redox state of Earth's mantle. Annu. Rev. Earth Planet. Sci. 36, 389-420 (2008).

15. Buseck, P. R. \& Huang, B.-J. Conversion of carbonaceous material to graphite during metamorphism. Geochim. Cosmochim. Acta 49, 2003-2016 (1985).

16. Zhang, C. \& Duan, Z. A model for C-O-H fluid in the Earth's mantle. Geochim. Cosmochim. Acta 73, 2089-2102 (2009).

17. Day, H. W. A revised diamond-graphite transition curve. Am. Mineral. 97, 52-62 (2012). 
18. Benedetti, L. R. et al. Dissociation of $\mathrm{CH}_{4}$ at high pressures and temperatures: diamond formation in Giant planet interiors?. Science 286, 100-102 (1999).

19. Kolesnikov, A., Kutcherov, V. G. \& Goncharov, A. F. Methane-derived hydrocarbons produced under upper-mantle conditions. Nat. Geosci. 2, 566 (2009).

20. Hirai, H., Konagai, K., Kawamura, T., Yamamoto, Y. \& Yagi, T. Polymerization and diamond formation from melting methane and their implications in ice layer of giant planets. Phys. Earth Planet. Inter. 174, 242-246 (2009). Advances in high pressure mineral physics: from deep mantle to the core.

21. Hazen, R., Mao, H., Finger, L. \& Bell, P. Structure and compression of crystalline methane at high pressure and room temperature. Appl. Phys. Lett. 37, 288-289 (1980).

22. Bali, E., Audétat, A. \& Keppler, H. Water and hydrogen are immiscible in Earth's mantle. Nature 495, 220-222 (2013).

23. Huang, F., Daniel, I., Cardon, H., Montagnac, G. \& Sverjensky, D. A. Immiscible hydrocarbon fluids in the deep carbon cycle. Nat. Commun. 8, 1-8 (2017).

24. $\mathrm{Li}, \mathrm{Y}$. Immiscible $\mathrm{CHO}$ fluids formed at subduction zone conditions. Geochem. Perspect. Lett. 3, 12-21 (2017).

25. Vitale-Brovarone, A. et al. Massive production of abiotic methane during subduction evidenced in metamorphosed ophicarbonates from the Italian Alps. Nat. Commun. 8, 1-13 (2017).

26. Griffin, W. L. et al. Super-reducing conditions in ancient and modern volcanic systems: sources and behaviour of carbon-rich fluids in the lithospheric mantle. Mineral. Petrol. 112, 101-114 (2018).

27. Ferrando, S., Frezzotti, M. L., Orione, P., Conte, R. C. \& Compagnoni, R. Latealpine rodingitization in the bellecombe meta-ophiolites (Aosta Valley, Italian Western Alps): evidence from mineral assemblages and serpentinizationderived $\mathrm{H}_{2}$-bearing brine. Int. Geol. Rev. 52, 1220-1243 (2010).

28. Boutier, A., Vitale-Brovarone, A., Martinez, I., Sissmann, O. \& Mana, S. Highpressure serpentinization and abiotic methane formation in metaperidotite from the Appalachian Subduction, Northern Vermont. Lithos 396, 106190 (2021).

29. Peng, W. et al. Abiotic methane generation through reduction of serpentinitehosted dolomite: implications for carbon mobility in subduction zones. Geochim. Cosmochim. Acta 311, 119-140 (2021).

30. Mao, H. K. et al. When water meets iron at Earth's core-mantle boundary. Natl Sci. Rev. 4, 870-878 (2017).

31. Mao, H.-K. \& Mao, W. L. Key problems of the four-dimensional Earth system. Matter Radiat. Extremes 5, 038102 (2020).

32. Malvoisin, B., Chopin, C., Brunet, F. \& Galvez, M. E. Low-temperature wollastonite formed by carbonate reduction: a marker of serpentinite redox conditions. J. Petrol. 53, 159-176 (2012).

33. Galvez, M. E. et al. Graphite formation by carbonate reduction during subduction. Nat. Geosci. 6, 473-477 (2013)

34. Moine, $\mathrm{B}$. et al. Molecular hydrogen in minerals as a clue to interpret $\partial \mathrm{D}$ variations in the mantle. Nat. Commun. 11, 1-10 (2020).

35. Penniston-Dorland, S. C., Kohn, M. J. \& Manning, C. E. The global range of subduction zone thermal structures from exhumed blueschists and eclogites: rocks are hotter than models. Earth Planet. Sci. Lett. 428, 243-254 (2015).

36. Dziewonski, A. M. \& Anderson, D. L. Preliminary reference earth model. Phys. Earth Planet. Inter. 25, 297-356 (1981).

37. Shimizu, H., Shimazaki, I. \& Sasaki, S. High-pressure Raman study of liquid and molecular crystal ethane up to 8 GPa. Jpn J. Appl. Phys. 28, 1632 (1989).

38. Kudryavtsev, D. et al. Raman and IR spectroscopy studies on propane at pressures of up to $40 \mathrm{GPa}$. J. Phys. Chem. A 121, 6004-6011 (2017).

39. Kudryavtsev, D. A., Kutcherov, V. G. \& Dubrovinsky, L. S. Raman highpressure study of butane isomers up to $40 \mathrm{GPa}$. AIP Adv. 8, 115104 (2018)

40. Wu, Y., Sasaki, S. \& Shimizu, H. High-pressure Raman study of dense methane: $\mathrm{CH}_{4}$ and $\mathrm{CD}_{4}$. J. Raman Spectrosc. 26, 963-967 (1995).

41. Somayazulu, M. S., Finger, L. W., Hemley, R. J. \& Mao, H. K. High-pressure compounds in methane-hydrogen mixtures. Science 271, 1400-1402 (1996).

42. Subramanian, N., Goncharov, A. F., Struzhkin, V. V., Somayazulu, M. \& Hemley, R. J. Bonding changes in hot fluid hydrogen at megabar pressures. Proc. Natl Acad. Sci. USA 108, 6014-6019 (2011).

43. Chou, I.-M. \& Anderson, A. J. Diamond dissolution and the production of methane and other carbon-bearing species in hydrothermal diamond-anvil cells. Geochim. Cosmochim. Acta 73, 6360-6366 (2009).

44. Beyssac, O., Goffé, B., Chopin, C. \& Rouzaud, J. Raman spectra of carbonaceous material in metasediments: a new geothermometer. $J$. Metamorph. Geol. 20, 859-871 (2002).
45. Hayes, J. M. \& Waldbauer, J. R. The carbon cycle and associated redox processes through time. Philos. Trans. R. Soc. Lond. B Biol. Sci. 361, 931-950 (2006).

46. Tumiati, S. et al. Dissolution susceptibility of glass-like carbon versus crystalline graphite in high-pressure aqueous fluids and implications for the behavior of organic matter in subduction zones. Geochim. Cosmochim. Acta 273, 383-402 (2020).

47. Tollan, P., Gurenko, A. \& Hermann, J. Elucidating the processes affecting highly primitive lavas of the Borgarhraun flow (Northern Iceland) using trace elements in olivine. Geochim. Cosmochim. Acta 286, 441-460 (2020).

48. Mukhina, E., Kolesnikov, A. \& Kutcherov, V. The lower PT limit of deep hydrocarbon synthesis by $\mathrm{CaCO}_{3}$ aqueous reduction. Sci. Rep. 7, 1-5 (2017).

49. Gregoryanz, E., Goncharov, A. F., Matsuishi, K., Mao, H. K. \& Hemley, R. J. Raman spectroscopy of hot dense hydrogen. Phys. Rev. Lett. 90, 4 (2003).

50. Howie, R. T., Dalladay-Simpson, P. \& Gregoryanz, E. Raman spectroscopy of hot hydrogen above 200 GPa. Nat. Mater. 14, 495-499 (2015).

51. Peña-Alvarez, M. et al. Intensity of Raman modes as a temperature gauge in fluid hydrogen and deuterium. J. Appl. Phys. 125, 025901 (2019).

52. Li, J., Redfern, S. A. T. \& Giovannelli, D. Introduction: deep carbon cycle though five reactions. Am. Mineral. 104, 465-467 (2019).

\section{Acknowledgements}

M.P.A. acknowledges the support of the UKRI Future leaders fellowship Mrc-Mr/ T043733/1. M.P.A. and E.G. acknowledge the support of the European Research Council (ERC) Grant 'Hecate' Reference number 695527 held by Professor Graeme Ackland. A.V.B acknowledges the support from the European Research Council (ERC) under the European Union's Horizon 2020research and innovation programme (Grant agreement No. 864045, ERC CoG DeepSeep) and from the Richard Lounsbery foundation. R.T.H. acknowledges the support of the National Science Foundation of China (Grant number 11974034) and ERC Grant 'MetElOne' Reference number 948895. The authors thank Josh Wood for the help with the Fig. 1.

\section{Author contributions}

M.P.A., A.V.-B. and E.G. planned the research. P.D.-S., E.G. and R.T.H. contributed materials/diagnostic tools. M.P.A., M.-E.D., M.W., P.D.-S. and R.T.H. carried out the experiments. M.P.A. analysed and interpreted the data. M.P.A., A.V.-B. and E.G. wrote the paper.

\section{Competing interests}

The authors declare no competing interests.

\section{Additional information}

Supplementary information The online version contains supplementary material available at https://doi.org/10.1038/s41467-021-26664-3.

Correspondence and requests for materials should be addressed to Eugene Gregoryanz

Peer review information Nature Communications thanks Dimitri Sverjensky and the other, anonymous, reviewer(s) for their contribution to the peer review of this work.

Reprints and permission information is available at http://www.nature.com/reprints

Publisher's note Springer Nature remains neutral with regard to jurisdictional claims in published maps and institutional affiliations.

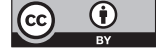

Open Access This article is licensed under a Creative Commons Attribution 4.0 International License, which permits use, sharing, adaptation, distribution and reproduction in any medium or format, as long as you give appropriate credit to the original author(s) and the source, provide a link to the Creative Commons license, and indicate if changes were made. The images or other third party material in this article are included in the article's Creative Commons license, unless indicated otherwise in a credit line to the material. If material is not included in the article's Creative Commons license and your intended use is not permitted by statutory regulation or exceeds the permitted use, you will need to obtain permission directly from the copyright holder. To view a copy of this license, visit http://creativecommons.org/ licenses/by/4.0/.

(C) The Author(s) 2021 